ISSN: 2215-2644

revedu@gmail.com

Universidad de Costa Rica

Costa Rica

\title{
Evolution of Educational Administration in Chile and Professionalizing School Administration in 2020
}

\author{
Yeomans Cabrera, María Mercedes \\ Evolution of Educational Administration in Chile and Professionalizing School Administration in 2020 \\ Revista Educación, vol. 46, núm. 1, 2022 \\ Universidad de Costa Rica, Costa Rica \\ Disponible en: https://www.redalyc.org/articulo.oa?id=44068165002 \\ DOI: https://doi.org/10.15517/revedu.v46i1.44499
}

\section{(c) $(1) \Theta$}

Esta obra está bajo una Licencia Creative Commons Atribución-NoComercial-SinDerivar 3.0 Internacional. 


\title{
Evolution of Educational Administration in Chile and Professionalizing School
} Administration in 2020

\author{
Evolución de la administración educativa en Chile y la profesionalización de la gestión escolar al 2020
}

Maria Mercedes Yeomans Cabrera

Universidad de Las Américas, Chile

mmyeomans@outlook.com

DOI: https://doi.org/10.15517/revedu.v46i1.44499

Redalyc: https://www.redalyc.org/articulo.oa?

$\mathrm{id}=44068165002$

iD https://orcid.org/0000-0003-2138-3007
Recepción: 26 Noviembre 2020

Aprobación: 04 Febrero 2021

\begin{abstract}
:
As is in many other countries, educational administration in Chile has adapted to the emerging needs of the country. In 2020 , a new public school educational system was gradually implemented, thereby, ending the municipal educational model established 40 years before by the military government. School administration has become more complex given the rise in schoolwide coverage. The objective of this study is to describe events that led to the current administration model using a timeline of policies pertaining to the educational system and the evolution of a professional career path for public school principals. This study is based on qualitative research using a descriptive approach based on a literature review. Public school administration efforts initially focused on school coverage and afterwards on improving the quality of education. The last few decades were characterized by educational reforms and paradigm innovations with an emphasis on school inclusion with a focus on non-profit education. Becoming a principal in the Chilean public school system is not an easy feat. Currently, Chile is considered to be one of the countries with the highest demands in accessing this position since it is based on merit with oversight based on the Law of Transparency. It is concluded that the rigorous nature of Chile's public educational administrative system should also extend to the private school system to ensure that administrative decisions will, most likely, be based on academic criteria and respect for each institution's educational goals.
\end{abstract}

KEYWORDS: Educational Administration, Education Policy, School Principals, Public Administration, School Administration.

\section{ReSUMEN:}

En Chile, como en otros países, la administración de la educación ha tenido que adaptarse a las necesidades emergentes. En el año 2020 se está implementando gradualmente el nuevo Sistema de Educación Pública para terminar con la Educación Municipal establecida por el Gobierno Militar hace alrededor de 40 años. El sistema administrativo se ha vuelto más complejo a medida que la cobertura escolar ha aumentado. El objetivo de esta investigación fue describir el camino recorrido para llegar a la administración actual. Como tareas específicas, se presentó una línea de tiempo de las normas que han conformado el sistema educativo y se analizó la profesionalización de los directores en las escuelas públicas. Se trató de una investigación cualitativa con enfoque descriptivo, basada en una revisión bibliográfica. La evolución de la administración educativa se ha centrado primero en la cobertura escolar y luego en la calidad de la educación. En las últimas décadas, hubo un proceso marcado por reformas y novedades de paradigmas, enfatizando la inclusión escolar y eliminando el lucro en la educación. En cuanto a la profesionalización de los directores de escuelas públicas, el modelo chileno se encuentra actualmente entre los países con mayores exigencias en cuanto al acceso al cargo, apoyado por la Ley de Transparencia, y centrado en el mérito. Como una oportunidad de mejora, se concluye que las demandas deben extenderse a los colegios privados para asegurar que las decisiones administrativas se tomen siempre con criterios académicos, respetando los proyectos educativos de cada institución.

Palabras clave: Administración educativa, Política educativa, Directores de escuela, Administración pública, Gestión escolar.

\section{INTRODUCTION}

In Chile, educational centers' administration has become more complex over time as school coverage has increased. When there are more students, there are also more schools that need to be managed correctly. This evolution has led to many adaptations of the scholar system in the country. Even there are many actions to 
take still, in 2016, Chile presented the best educational coverage rate in Latin America-almost universal coverage in primary education (99.4\%) and the best scores in standardized tests, such as PISA and TERCE, not to mention that Chile has the highest graduation rate in Latin America (Banco de Desarrollo de América Latina, 2016). However, public and private schools in Chile are very diverse. Moreover, parents have been enrolling their children in private schools, more and more every year (Ministerio de Educación de Chile, 2015a, 2017).

During the three past decades, Municipalities nationwide were the stakeholders of public schools. The Military Government promoted municipal administration to have local management of schools and other public services since a centralized model made all processes non-efficient; though, the technology of the time and the context of the country must be considered. The decision to transfer the establishments' administration was organized under the subsidiarity principle that guided the Military Government's work. According to this principle, it is desirable to allow private individuals' participation in activities where the State should not necessarily be the sole provider. Private persons, natural or legal, were allowed to create private subsidized primary and secondary education institutions; in higher education it was allowed for privates to create and manage technical training centers, professional institutes, and universities (Dittborn, 2021; Ministerio del Interior de Chile, 1979). It is essential to keep in mind that at that time, due to the economic difficulties the State was going through, it seemed convenient for individuals to contribute with their effort and resources, otherwise many urgent needs could have been impossible to assume. This was the most important economic and social crisis that affected the country in the 20th century (Dittborn, 2021).

In 2015 the President introduced a bill to create a Public Education System (PES) and modify other legal bodies associated with education. In 2020, after more than thirty years of municipal administration of education - since the government of Augusto Pinochet - a new type of administration is being implemented by Law 21,040. Seventy Local Public Education Services (LPES) were created and linked to the executive through the Ministry of Education, which covers all the municipalities in the country. The purpose of the services is to provide the educational service through the establishments of their dependency and ensure quality, continuous improvement, and equity with technical and pedagogical support, and management support, while respecting their autonomy. The Direction of Public Education (DPE) answers the Ministry of Education and supervises the LPES (Ministerio de Educación de Chile, 2017).

Municipalization was an administrative decision to decentralize the management of education. Today, demunicipalization is a mixture of municipalization and a new centralization of the system. It takes municipalities out of the equation (Biblioteca del Congreso Nacional de Chile, 2018). The process of demunicipalization started at the beginning of 2020, and, up to October 2020, seven out of seventy LPES have been established in the national territory, and nearly 400 educational establishments in 25 municipalities have been transferred, with an approximate enrollment of 108,000 students (Ministerio de Educación de Chile, 2020a). It is essential to analyze the characteristics of the Chilean educational system and the educational policies' situation after having a panoramic vision of the decisions that have been made.

The main objective of this research was to describe the road traveled to reach the current administration. The specific objectives were to present a timeline of the norms that have shaped the education system and to analyze the school principals' professionalization in public schools. This was qualitative research with a descriptive approach, based on a literature review. In order to understand the current school administration and management in Chile, the next sections consist of a chronogram of the advances in school coverage, the evolution of the State's administration of education, the current form of access to the position of school principal in the country, and a comparison with other management models. 


\section{Evolution of the State Administration on Education}

In Chile, education began to be considered a function of the State when the constitution of 1833 declared that education was the government's preferential attention. It also declared that a national education plan would be formed through Congress, that there would be a superintendency of education, and that existing municipalities should promote education and take care of schools. At that time, education was under the Ministry of Justice (Gobierno de Chile, 1888). Four years later, the functioning of the different ministries was decreed. The Ministry of Justice would be responsible for public instruction, educational establishments promotion, the opening of schools and other educational institutions authorizations, and interaction with educational institutions, officials and authorities of the republic in matters concerning public instruction. It would also appoint and retire employees of this branch (Portales, 1837). When the Law of Elementary Instruction was enacted - which identified two classes of school: elementary and higher-, convents and monasteries would be obliged to create schools for men and women, separately, and would adhere to free instruction. Schools - paid by the public treasury - would be created for training preceptors. In order to take up the post, they would have to accredit a good life and costumes, and being certified in a normal school. Failing that certification, they would have to show the necessary aptitudes through an exam, university degree, or certificate of a school principal. The preceptors could not be individuals that had been prosecuted or convicted for crimes that merited a penalty of grief or infamy, nor persons who had been removed from their posts for immorality or bad habits; the preceptors became public employees. A single-person post was established for the general inspection, which directed visiting persons who supervised the educational establishments. Finally, it was stated that private instruction was not subjected to this law, concerning teaching and methods (Gobierno de Chile, 1860). Almost twenty years later, the Law of Secondary and Higher Education was enacted, which secured State funds to finance higher education establishments, special education establishments, and secondary education establishments. Furthermore, it was allowed that any legal or natural person could establish secondary or higher education institutions, as long as the law did not prohibit it. Having all the existing education levels free of charge, diversity in the educational offer, and a fiscal superintendence of secondary and higher education, the number of establishments and the school coverage increased (Anguita, 1913).

In 1920, the Compulsory Primary Education Law was passed, which established that primary education was free but also a duty for the first four years; this duty fell on the parents or persons in charge of the children and must be fulfilled before the age of 13. It also established that the two first years of primary education could be carried out in the homes by giving an annual evaluation to measure the process. This would be the first regulation of the homeschooling system in Chile. The Direction of the Primary Education would supervise the fulfillment of this law's norms through people who visited the educational establishments. Besides each establishment's internal direction, the Board of Education of each commune was created to help the supervision. This consisted of 10 people-five by cumulative vote, two by the Council of Primary Education, and three by the pertinent municipality - , positions that had to be renewed every three years; the person directing the communal school would serve as secretary of the Board of Education (Ministerio de Instrucción Pública de Chile, 1920). Five years later, the Public Instruction's rules and internal functioning were established for the first time, determining its sections and departments through Law Decree No. 800 (Ministerio de Educación de Chile, 1995). Soon, the Ministry of Public Education was created and separated from the Ministry of Justice. The new institution took on the challenge of planning and administering education; it was also established that state education was free (Biblioteca Nacional de Chile, 2020). Almost simultaneously, the Ministry of Public Education was organized in administrative aspects; positions were created for five departments: a) Administrative, b) Primary Education, c) Secondary Education, d) Physical Education, and e) Artistic Education and Cultural Extension (Ministerio de Educación Pública de Chile, 
1928). In 1938 a particular focus was placed on expanding primary education; more than 500 schools were built, and the number of enrolled students increased by nearly 600\% (Revista de Educación, 2017).

In 1965 the educational system was reformed to develop better quality, harmony, and integration of all individuals' aspects (Ministerio de Educación Pública de Chile, 1965). To accelerate school coverage, the Center for Pedagogical Improvement, Experimentation, and Research (CPEIP) was created, concentrating all instances of teacher improvement that existed at that time (Ministerio de Educación Pública, 1967). The institution's objective was to quickly instruct teachers in the pedagogical principles promoted by the recent reform; it also aimed to reach teachers located in more remote areas with technical assistance from the center's professionals (Revista de Educación, 2017). The CPEIP was also in charge of training the technical personnel in the Ministry of Education (Mineduc). For this purpose, agreements were signed with the Organization of American States, Unesco, and the United Nations Organization, among others. The importance of having experts for the direction of education is recognized, so the CPEIP gave courses to prepare people in educational planning, administration, supervision, and other specialties with the participation of students and teachers from all over the continent (Revista de Educación, 2017).

In 1973, during the Military Government, it was established to decentralize education with regional coordinations (Ministerio de Educacio\#n Pu\#blica de Chile, 1973). The next year, territories were defined to divide the country for educational administration, and with this, the Regional Ministerial Secretariats were created (Ministerio de Interior de Chile, 1974). At the end of the decade, a decree on Municipal Revenues was enacted, which empowered municipalities to administer services that were centralized to date. The Municipal Common Fund was also created, expressly establishing that the resources allocated to it from that moment on should be consigned to develop, maintain, and provide them to the local community. Those resources came from the national treasury, which had previously been given to the centralized public distributions. Since then, the municipalities could take on benefits that to date were only being provided by central bodies in the public or private sector. Municipalities started administrating health care, public works, citizen security, and administration of educational establishments, among others (Ministerio de Hacienda de Chile, 1980).

As it has been pointed out, this step required profound transformations in the legislation related to municipal administration and other legal bodies that would make it possible to finance the municipalities' establishments. The Subsidy Law was amended to extend the school grant to the city administration. At the time of this change, the subsidies were substantially increased. They began to be given to free private schools and schools whose administration began to be transferred to the municipalities (Ministerio del Interior de Chile, 1979). Municipalization had the purpose of decentralizing the educational administration's managing tasks, bringing it closer to the communities. In summary, it meant maintaining the necessary staff of teachers, principals, and educational assistants for the schools' proper functioning during the year and making maintenance and improvements in infrastructure effectively. In the Ministry of Education, the responsibilities for educational subjects were maintained. This refers to the definition of teaching content, national curriculum, standards, school text delivery, teacher training, special program definition, national standardized evaluations, and all the technical, pedagogical support, and supervision municipalities will undoubtedly need. The Ministry's relationship with the municipalities was then carried out through the Ministerial Secretariats of Education and their Provincial Directorates (Ministerio de Educación Pública, 1980). The municipalization of education was established; schools and high schools were transferred from the Ministry of Education to the municipal administration of their geographical location (Ministerio del Interior de Chile, 1979). After the municipalization process in the 1980s, public school management's decentralized selection started (Núñez et al., 2010).

Back in democracy, the Organic Constitutional Law on Education (LOCE) was published, establishing minimum primary and secondary education requirements. The State's duty was to ensure compliance and 
establish standards for the official recognition of educational establishments and systematizing a process for all existing levels (Ministerio de Educación de Chile, 1990).

\section{The Current Administrative Model}

In 2003, a Constitutional Reform was carried out that established free and compulsory schooling from the first year of primary education until the completion of secondary education, that is, 12 years (Ministerio de Educación de Chile, 2003). In 2005, the managers' position desirable requirements, and maximum duration, were indicated as mandatory for municipal education, setting a gradual replacement schedule for the existing universe (Ministerio de Educacio\#n de Chile, 2005). The General Education Law (LGE), promulgated in 2009, insists on mandatory selection through competition in the public sector (Núñez et al., 2010).

To enforce the results proposed by the Ministry, the Law on Quality and Equity in Education increases the powers of municipal supporters through the municipal line of responsibility-heads of Municipal Administration, managers of establishments, and school principals. The law is aligned with the school system's decentralized design (Ministerio de Educacio\#n de Chile, 2011). This same law professionalized the system even more by installing a public and transparent procedure. Each stage of selection for the manager/ principal's position is open from the municipality, which generates an ideal profile for the position. To carry it out, an independent qualifying commission is formed, which consists of three people: one who is a senior public management advisor (ADP), one who is a teacher in the municipality, and the head of education; after evaluating the candidates, the commission presents a list of three to five people to the municipal supporter, who finally chooses the principal (Ministerio de Educacio\#n de Chile, 2011). The general profile establishes that the candidates must, obligatorily, have a teacher's diploma, except for those with another bachelor's degree. They also need at least three years of experience as classroom teachers, improvement in school management areas, and at least five years of experience, ensuring their abilities, related studies, and empirical knowledge of classroom teaching. The law also mentions, as desirable characteristics, experience in management, coordination and/or leadership positions, and the demonstration of competencies, such as pedagogical leadership, people management, and achievement, characteristics that point directly to human resource management. Concerning implementation, the law dictated that, by 2016, all management positions in municipal schools should be selected by this means. However, this policy's progress by 2016 was $65 \%$, with the selection of management positions by ADP occurring in a more significant proportion in urban, less vulnerable, and large establishments (Agencia de Calidad de Educación, 2016). This irregularity meant that the more vulnerable and smaller rural schools did not select their principals with the same rigor, leaving them disadvantaged. Considering that this was a measure included in the law on Quality and Equity in Education, it was expected to provide vulnerable and smaller rural schools with the best candidates.

In the same year that the Law on Quality and Equity in Education was passed, 2011, Law No. 20,529 created the National System of Quality Assurance of Nursery, Basic and Secondary Education and its Supervision. The four institutions that make up this system are the Agency for Quality in Education and the Superintendent of Education - both created by this law-, the National Council of Education - which replaced the Higher Council of Education-, and the Ministry of Education. The latter has the function of governing body, develops the sector's policies, elaborates the curricular bases and standards on which the Assurance System is based, and provides technical-pedagogical support to the institutions that need it (Ministerio de Educación de Chile, 2011).

In 2015, the Law on School Inclusion was enacted. It put an end to the misuse of public resources in the educational system, presented an admission system for schools with regular contributions from the State, and established progressive free education by increasing resources allocated to educational quality (Ministerio de Educación de Chile, 2015b). 
Even though the municipalized administration is still working, some issues could not be overcome over the years. Firstly, there are municipalities with more own resources than others, so it was foreseeable that those with funds beyond school subsidies could improve their teachers' working conditions and the quality of their infrastructure sooner. The Municipal Common Fund, created in 1979, is a mechanism that aims at fiscal equity. All the municipalities make contributions. Then, each municipality receives a proportion of the fund collected, determined by a distribution formula that depends on the following components: number of municipalities, population, the relative importance of exempt land, poverty, and income collected (Bravo, 2014). The amount of the subsidy by region is sometimes not sufficient for those municipalities with few children and little communal income in general. With municipalization, municipalities took charge of delivering health, public works, and citizen security, among other responsibilities added to their chores (Ministerio del Interior de Chile, 1979). Therefore, education needs were not the only ones to be addressed. Over the years, there has also been a significant increase in subsidized private schools' educational offerings in all of the country's municipalities, which have attracted children and reduced municipal attention; therefore, municipalities' income from this concept has been reduced (Ministerio de Educación de Chile, 2015a). For these reasons, the Public Education System (PES) was created, whose new organization is being implemented gradually starting in 2020 and will put an end to municipal administration (Biblioteca del Congreso Nacional de Chile, 2018). The principles of the new PES are (a) Integral quality, (b) continuous quality improvement, (c) national coverage and guaranteed access, (d) equitable development and equal opportunities, e) collaboration and networking, ( $\mathrm{f}$ ) inclusive and educational projects and citizen training, (g) local relevance, diversity in projects and community participation, (h) citizen training and republican values, and (i) integration with the environment and the community (Ministerio de Educación de Chile, 2017).

\section{School’s Principals}

In 2016, through Law No. 20,903, the Teacher Professional Development System was created (Ministerio de Educación de Chile, 2016a). One of the main points of this law is the projection of an average increase of $30 \%$ in teachers and nursery educators' salaries from July 2017. Besides, in March of the same year started the increase of $30 \%$ of the hours destined for planning - which involves preparing and evaluating classes - with the goal of $35 \%$ of the hour destined for these purposes by 2019 (Agencia de Calidad de Educación, 2016). In the case of teachers with a full schedule ( 44 hours), before this law, they only had 11 hours for planning, preparing material, answering e-mails, and checking tests. For the year 2017, they could be assured 13 hours and 15 minutes for work outside the classroom. Then, in 2019, this time would increase to 15 hours and 30 minutes in an attempt to allow teachers to perform all their work in educational establishments without using their unpaid personal time.

This same law establishes that, from 2017, only those in the advanced section-teachers with four years of experience who obtain the highest achievement in the portfolio instrument [A]-will access management positions in the municipal sector. This section is characterized by achieving the skills indicated in the Framework for Good Teaching, such as classroom teaching skills, pedagogical reflection, and participation in mentoring roles and design of school improvement programs (Ministerio de Educación de Chile, 2016a). Concerning the selection of the position of principal of particular establishments, the norm does not regulate its operation. Principals' election is on the opinion of each establishment's stakeholders.

The recruitment system for the principals of public establishments based on Law 20,501, which places people's capacities beyond their seniority and experience in the system at the center, has represented a tremendous advance for the country (Ministerio de Educacio\#n de Chile, 2011). It is important to emphasize that the data suggest that principals selected by ADP show signs of more excellent managerial and pedagogical leadership than people who were not selected via ADP; this new policy's value, which allows people with 
adequate skills and recruited transparent processes, is precisely generating relevant differences in the system and should be strengthened by the meritocratic principle that upholds (Agencia de Calidad de Educación, 2016).

Since 2014, the CPEIP has begun to update the Framework for Good School Leadership, born in 2005. The document includes national and international advances in theoretical conceptualizations, research findings, and school leadership. Many actors have constructed this framework: members of the School Leadership Advisory Councils from all regions of the country, academic bodies from higher education institutions in different areas of the country, regulatory bodies, people in the coordination of programs that participated in the Principals' Training Plan, Mineduc teams and-in its final stage-the collaboration of all the school boards from the 15 regions of Chile to evaluate the product. Thus, this document constitutes a working instrument validated in its relevance, internal coherence, and centrality of the elements presented, which guide the management task and strengthen the leadership of the country's management teams (Uribe et al., 2015).

According to the General Education Law, the entire educational community plays an essential role in schools. This community consists of students, parents, guardians, educational professionals, educational assistants, educational management teams, and educational supporters. They must also develop professionally and promote the necessary professional development in the teaching staff to meet their educational goals and comply with and respect their rules. On the other hand, educational institutions' supporters have the right to establish and exercise an educational project with the educational community (Ministerio de Educación de Chile, 2019).

Considering that not all management teams are the same in the great diversity of existing establishments, it is essential to point out the trend in forming these teams. There is a significant presence of principal positions throughout the country, head of the Technical Pedagogical Unit (UTP), and general inspection. The larger the establishment, the larger the management team's size, and, consequently, there are more positions other than the triad of principal, head of UTP, and general inspection. Comparing the establishments' size, it is shown that both general inspectors and guidance counselors are present in a more significant proportion in medium and large establishments than small ones. Deputy Principals are also present in a more significant proportion of large establishments (Ministerio de Educación de Chile, 2016b). According to the Chilean Ministry of Education, management teams must be promoters of an organizational culture based on collaboration, communication, commitment, and actions' institutionalization. They must also promote a sense of belonging and identity among all educational community members by involving them in information, more significant roles, functions, and responsibilities in the common objectives (Ministerio de Educación de Chile, 2020b). All educational establishments must have a person in charge of school coexistence. This person will be responsible for implementing the measures determined by the School Board or the Committee for Good School Coexistence and included in a management plan (Ministerio de Educación de Chile, 2018, 2019).

\section{The Chilean Management Model, compared to other countries}

When comparing the Chilean management model with the common European and United States models, some similarities and differences can be found. To carry out this comparison, the classification of management models presented by Alvarez (1991) (Official Centralist, Decentralized Market, and Participatory Centralist) and current policies documentation concerning the Chilean educational system were used; a total of eight papers (Alvarez, 1991; Agencia de Calidad de Educación 2016; Ministerio de Educación de Chile, 2011; Ministerio de Educación, 2016a; Ministerio de Educación, 2016b; Ministerio de Educación de Chile, 2018; Ministerio de Educación de Chile, 2019; Uribe et al., 2015). Considering that the models just mentioned are mainly European, a comparative table has been constructed where the American 
and Chilean models are included separately. The dimensions for comparison in Table 1 are 1) access to the principal's position, 2) initial and continuing education of the principal, and 3) functions of the principal. 
TABLE 1

Comparison of the Chilean School Management Model with the Functional Centralist Model, Decentralized Market Model, Participatory Centralist Model, and the American Model, at 2020

\begin{tabular}{|c|c|c|c|}
\hline MODEL & $\begin{array}{l}\text { ACCESS TO } \\
\text { THE POSITION }\end{array}$ & TRAINING & FUNCTIONS \\
\hline CHILEAN & $\begin{array}{l}\text { Selection: } \\
\text { Presentation of } \\
\text { candidates by } \\
\text { an independent } \\
\text { qualification } \\
\text { committee } \\
\text { (Director of } \\
\text { Senior Public } \\
\text { Management, } \\
\text { Head of } \\
\text { Education, and } \\
\text { municipality } \\
\text { teachers). } \\
\text { Candidate's } \\
\text { election by the } \\
\text { supporter } \\
\text { based on the } \\
\text { bank of } \\
\text { profiles of } \\
\text { Mineduc that } \\
\text { corresponds to } \\
\text { the } \\
\text { establishment. } \\
\text { Requirement: } \\
\text { to be } \\
\text { hierarchical in } \\
\text { the advanced } \\
\text { section ( } 4 \text { years } \\
\text { of teaching and } \\
\text { evaluation } \mathrm{A} \text { ). }\end{array}$ & $\begin{array}{l}\text { Initial and } \\
\text { ongoing training } \\
\text { by the } \\
\text { individual. }\end{array}$ & $\begin{array}{l}\text { To direct, administer, } \\
\text { supervise, and coordinate } \\
\text { education. It involves direct } \\
\text { supervision and } \\
\text { responsibility for students } \\
\text { and teaching staff, teachers, } \\
\text { administrative, auxiliary, or } \\
\text { other minor services. }\end{array}$ \\
\hline $\begin{array}{l}\text { OFFICIAL } \\
\text { CENTRALIST }\end{array}$ & $\begin{array}{l}\text { Selection: by } \\
\text { the Central } \\
\text { State } \\
\text { Requirement: } \\
\text { Teacher } \\
\text { Criteria: CV, } \\
\text { experience, } \\
\text { inspector's } \\
\text { reports, } \\
\text { superior's } \\
\text { reports. }\end{array}$ & $\begin{array}{l}\text { Initial basic } \\
\text { training by the } \\
\text { individual. Little } \\
\text { attention to } \\
\text { ongoing training } \\
\text { by the } \\
\text { administration. }\end{array}$ & $\begin{array}{l}\text { Responsible for the people, } \\
\text { the goods, and the } \\
\text { organization of the } \\
\text { establishment. }\end{array}$ \\
\hline $\begin{array}{l}\text { DECENTRALIZED } \\
\text { MARKET }\end{array}$ & $\begin{array}{l}\text { Selection: by } \\
\text { local } \\
\text { authorities } \\
\text { Requirement: } \\
\text { Teacher } \\
\text { Criteria: CV, } \\
\text { experience, } \\
\text { inspectors' } \\
\text { reports, } \\
\text { superiors' } \\
\text { reports. } \\
\text { Relatively } \\
\text { lifetime } \\
\text { position with } \\
\text { transfer to } \\
\text { other } \\
\text { establishments. }\end{array}$ & $\begin{array}{l}\text { Formation of the } \\
\text { principal in } \\
\text { charge of the } \\
\text { administration. }\end{array}$ & $\begin{array}{l}\text { Administration-Management; } \\
\text { relationship and negotiation } \\
\text { with the social and } \\
\text { institutional forces that } \\
\text { constitute its environment. } \\
\text { Responsibility for budgets. } \\
\text { Performance bonuses. }\end{array}$ \\
\hline $\begin{array}{l}\text { PARTICIPATORY } \\
\text { CENTRALIST }\end{array}$ & $\begin{array}{l}\text { Selection: } \\
\text { School Board } \\
\text { Requirement: } \\
\text { Teacher } \\
\text { Democratic } \\
\text { election by } \\
\text { votes } \\
\text { Temporary } \\
\text { position. }\end{array}$ & $\begin{array}{l}\text { Training in } \\
\text { charge of the } \\
\text { person, not } \\
\text { institutionalized. }\end{array}$ & $\begin{array}{l}\text { It shares power with the } \\
\text { collegiate body, encouraging } \\
\text { and integrating functions } \\
\text { rather than administrative } \\
\text { and management (the latter } \\
\text { two remain uncovered). }\end{array}$ \\
\hline UNITED STATES & $\begin{array}{l}\text { Selection: by } \\
\text { local } \\
\text { authorities } \\
\text { Prerequisite: } \\
\text { Academic } \\
\text { Degree and } \\
\text { State } \\
\text { Certification } \\
\text { Criteria: CV, } \\
\text { experience, } \\
\text { inspectors' } \\
\text { reports, } \\
\text { superiors' } \\
\text { reports. } \\
\text { Relatively } \\
\text { lifetime } \\
\text { position. }\end{array}$ & $\begin{array}{l}\text { The training of } \\
\text { the principal is } \\
\text { in charge of the } \\
\text { individual. }\end{array}$ & $\begin{array}{l}\text { Organization and } \\
\text { management, effective } \\
\text { school and school } \\
\text { leadership, maintenance, } \\
\text { supervision, direction, and } \\
\text { leadership. }\end{array}$ \\
\hline
\end{tabular}


When comparing the Chilean model with the Official Centralist Model, some similarities in initial and permanent formation are found; these are in charge of the individual. Also, some similarities concerning the functions related to persons, goods, and organization were identified. However, there are significant differences in access to the position. In the Chilean model, the selection is more complex, and the requirements are more significant.

When comparing the Chilean model with the Decentralized Market Model, there are more differences than similarities. Concerning access to office, the Chilean model is more complex, and the requirements are more significant. Concerning the formation of the principal, in Chile, the individual is in charge, and in the Decentralized Market Model, it is in charge of the administration. Finally, it is evidenced that, in the Chilean model, the principal has more functions within the organization. Simultaneously, the present European model also has relationships and negotiations with external institutional and social forces.

When comparing the Chilean model with the Participatory Centralist Model of European countries, there were found more differences than similarities. Concerning access to office, the Chilean model is more complex, focused on merit, and the requirements are more significant; besides, this European model makes its Principals' election by democratic vote. Regarding training, in both models, the individual is in charge. Moreover, concerning functions, administration, and management are not covered by the principal, as in the Chilean system.

When comparing the Chilean model with the United States model, the results are similar to those compared to the Decentralized Market Model. However, the U.S. model's requirements are higher, coming closer to the Chilean model. In the United States, an academic degree and state certification are required. In Chile, a teacher's degree or academic degree and certification from the Ministry of Maximum Qualification in Teaching Careers are required. Concerning training, in both countries, it is the responsibility of the individual. Furthermore, concerning the functions, no differences are seen.

Although all models tend to evolve based on society's needs, all models are perfectible based on permanent change. Regarding access to the position, the Chilean model has a profile bank, a greater demand in the requirements, and a council that filters the participants before their election based on the law of transparency. The only model that resembles the Chilean model concerning the management position's professionalization is the American one. The furthest model from the professionalization of the principal is the Participatory Centralist Model. Due to the access to the position by democratic vote, there is the possibility of a conflict of interest that could distract the principal from their functions.

In the training dimension, it can be seen that the Participatory Centralist Model is the only one in which the administration is fully responsible for the permanent training of the management position. In all the other models, the permanent formation is in charge of the individual. Suppose the administration were to take charge of the permanent formation of the principals of all public institutions. In that case, one could speak of more significant equity by ensuring basic knowledge concerning curricular and social updates, among others.

Finally, only the Participatory Centralist Model leaves administration and management aspects outside the principal's functions. In all the other models reviewed, including the U.S. and Chilean models, management includes the functions of administering and managing resources, which could lead to decisions being made, always taking into account the academic aspects involved. Of course, the person in charge of school leading must be trained in administration and management since it can be challenging to lead an organization when others manage resources. 


\section{Conclusions}

Responding to the first specific objective, which was to present a timeline of the norms that have shaped the education system, it is concluded that the administration of Chilean public education has become more complex over the years as school coverage has grown. Since 1833, due to the national constitution, education became a government priority. Significant changes have been made by creating different departments, arriving at a Ministry of Education with an active Center for Improvement, Experimentation, and Pedagogical Research, and a Quality Agency. In recent decades, a process marked by reforms and paradigm shifts has developed, emphasizing quality, school inclusion, and eliminating profit in education. Municipalization had a significant role in the Chilean history of education. From a geographical, economic, and administrative point of view, it responded to many needs of the time, promoting school coverage at all educational levels and diversity of educational projects. In 2020 this administration model started changing due to the new Public Education System and the need to focus mainly on quality, above any other scopes.

Responding to the second specific objective, which was to analyze the school principals' professionalization in public schools, it is concluded that the Chilean model is currently among the countries with the highest demands in access to the position, supported by a Law of Transparency and focused on merit. As an opportunity for improvement, it can be seen that all these demands point only to public establishments, even though private establishments are working with the education of a significant group of the Chilean society. Therefore, some minimum requirements should be considered in private education to assure that the centers' administrative decisions are always considering an academic scope and respecting each of the institutional educational projects.

Finally, responding to this research main objective, which was to describe the road traveled to reach the current administration, it is concluded that the evolution of educational administration has been focused first on school coverage and then on quality in education, responding to the contexts and resources available. Chile has come to be a country with complex administration and leading Latin American indicators by continuously adapting the system to emerging scenarios.

\section{REFERENCES}

Agencia de Calidad de Educación. (2016). Directores municipales seleccionados mediante la ley $N .^{\circ} 20501$. Santiago de Chile. https://bibliotecadigital.mineduc.cl/bitstream/handle/20.500.12365/4570/directoresmunicipales.p df? sequence $=1 \&$ is Allowed $=\mathrm{y}$

Alvarez, M. (1991). El panorama europeo. Cuadernos de Pedagogía, 189, (pp.16-19). https://www.scribd.com/docu ment/511560414/El-Panorama-Europeo

Anguita, R. (1913). Leyes Promulgadas en Chile. Santiago de Chile. https://obtienearchivo.bcn.cl/obtienearchivo?id $=$ recursoslegales $/ 10221.3 / 32755 / 1 /$ anguita18790109.pdf

Banco de Desarrollo de América Latina. (2016, november 28th). Chile es uno de los pai\#ses con mejor educacio\#n en Ame\#rica Latina, pero debe trabajar ma\#s en calidad. https://bit.ly/33VHhNG

Biblioteca del Congreso Nacional de Chile. (2018). Historia de la Ley 21.040. https://www.bcn.cl/historiadelaley/n c/historia-de-la-ley/vista-expandida/7106/\#h1_1_1

Biblioteca Nacional de Chile. (2020). Ministerio de Educación Pública. http://www.memoriachilena.gob.cl/602/w3 -article-96125.html

Bravo, J. (2014, June). Fondo Común Municipal y su desincentivo a la recaudación en Chile. https://bit.ly/33SuqLY

Dittborn, P. (2021). El contexto histo\#rico de la Municipalizacio\#n. https://www.grupoeducar.cl/revista/edicion-194 /contexto-historico-la-municipalizacion/

Gobierno de Chile. (1888). Constitución Politica de la República de Chile. Pub. L. No. S/N, Biblioteca del Congreso Nacional. Chile: Biblioteca del Congreso Nacional. https://www.leychile.cl/N?i=137535\&f=1888-08-10\&p= 
Gobierno de Chile. (1860). Instrucción Primaria. Lei Jeneral del Ramo. Biblioteca del Congreso Nacional de Chile. h ttps://www.leychile.cl/Navegar?idNorma $=1022941$

Ministerio de Educación de Chile. (1990). Ley 18.962. Biblioteca del Congreso Nacional de Chile. https://www.ley chile.cl/N?i=30330\&f $=2005-09-27 \& \mathrm{p}=$

Ministerio de Educación de Chile. (1995). Documentos, 1901-1995. http://www.patrimoniocultural.gob.cl/Recurso s/Contenidos/ArchivoNacional/archivos/MinisteriodeEducación.pdf

Ministerio de Educación de Chile. (2003). Ley 19.876. Biblioteca del Congreso Nacional de Chile. https://www.ley chile.cl $/ \mathrm{N} ? \mathrm{i}=210495 \& \mathrm{f}=2003-05-22 \& \mathrm{p}=$

Ministerio de Educacio\#n de Chile. (2005). Ley 20.006. Biblioteca del Congreso Nacional de Chile. https://www.le ychile.cl/Navegar?idNorma $=236496$

Ministerio de Educacio\#n de Chile. (2011). Ley 20.501. Biblioteca del Congreso Nacional de Chile. https://www.le ychile.cl/Navegar?idNorma $=1022346$

Ministerio de Educación de Chile. (2011). Ley 20.529. Biblioteca del Congreso Nacional de Chile. https://www.ley chile.cl/N?i=1028635\&f=2019-04-25\&p=LEYNÚM.20.529

Ministerio de Educación de Chile. (2015a). Variación de matrícula y tasas de permanencia por sector. https://centroes tudios.mineduc.cl/wp-content/uploads/sites/100/2017/06/Evidencias-final_julio_2015.pdf

Ministerio de Educación de Chile. (2015b). Ley 20.845. Biblioteca del Congreso Nacional de Chile. https://www.le ychile.cl/N?i=1078172\&f=2019-04-25\&p=

Ministerio de Educación de Chile. (2016a). Ley 20.903. Biblioteca del Congreso Nacional de Chile. https://www.le ychile.cl/N?i=1087343\&f=2019-12-21\&p=

Ministerio de Educación de Chile. (2016b). Estudio de Caracterizacio\#n de los Equipos Directivos Escolares de Establecimientos Educacionales Subvencionados Urbanos de Chile. http://biblioteca.digital.gob.cl/handle/12345 $6789 / 405$

Ministerio de Educación de Chile. (2017). Ley 21.040. Pub. L. No. 21040. Biblioteca del Congreso Nacional de Chile. http://bcn.cl/2eoy3

Ministerio de Educación de Chile. (2018). Consejo Escolar, pilar de la participación en la comunidad educativa. http:/ /convivenciaescolar.mineduc.cl/wp-content/uploads/2019/04/Consejo-Escolar-2018.pdf

Ministerio de Educación de Chile. (2019). Ley General de Educación 20.370. Biblioteca del Congreso Nacional. http s://www.leychile.cl/N?i=1014974\&f=2019-06-27\&p=

Ministerio de Educación de Chile. (2020a). Educación Pública. https://educacionpublica.cl

Ministerio de Educación de Chile. (2020b). Equipos docentes directivos. http://convivenciaescolar.mineduc.cl/comun idad-educativa/equipos-docentes-directivos/

Ministerio de Educación Pública. (1967).Decreto 6.494. Pub. L. No. 6494. Biblioteca del Congreso Nacional de Chile. https://www.leychile.cl/N?i=140197\&f=1969-02-07\&p=

Ministerio de Educación Pública. (1980). Decreto 8144. Pub. L. No. 8144. Biblioteca del Congreso Nacional de Chile. http://bcn.cl/2haaj

Ministerio de Educación Pública de Chile. (1928). Decreto No 7500. Santiago de Chile. http://www.bibliotecanacio naldigital.gob.cl/visor/BND:86462

Ministerio de Educación Pública de Chile. (1965). Decreto 27.952. Biblioteca del Congreso Nacional de Chile. https ://www.bcn.cl/leychile/navegar?idNorma=19478\&idParte=

Ministerio de Educación Pu\#blica de Chile. (1973). Decreto 1.586. Biblioteca del Congreso Nacional de Chile. http s://www.leychile.cl/N?i=1045958\&f $=1973-11-08 \& \mathrm{p}=$

Ministerio de Hacienda de Chile. (1980). Traspaso de servicios Públicos a las Municipalidades. Manual de Consulta. Santiago de Chile. https://bit.ly/3eYIKc2

Ministerio de Instrucción Pública de Chile. (1920). Ley 3.654. Biblioteca del Congreso Nacional. Chile. https://ww w.leychile.cl/Navegar?idNorma $=24146$ 
María Mercedes Yeomans Cabrera. Evolution of Educational Administration in Chile and Professionali...

Ministerio de Interior de Chile. (1974). Decreto de Ley 575. Biblioteca del Congreso Nacional de Chile. https://ww w.leychile.cl/N?i=6210\&f $=2002-10-15 \& \mathrm{p}=$

Ministerio del Interior de Chile. (1979). Decreto Ley 3063. Pub. L. No. 3063. Biblioteca del Congreso Nacional de Chile. http://bcn.cl/2euls

Núñez, I., Weinstein, J. \& Muñoz, G. (2010). ¿Posición olvidada? Una mirada desde la normativa a la historia de la dirección escolar en Chile. Psicoperspectivas, 9, (pp.53-81). https://doi.org/10.5027/psicoperspectivas-Vol9-Iss ue2-fulltext-117

Portales, D. (1837). Decreto S/N. Pub. L. No. S/N. Biblioteca del Congreso Nacional de Chile. http://www.leychile $. c l / \mathrm{N} ? \mathrm{i}=1063940 \& \mathrm{f}=1837-02-01 \& \mathrm{p}=$

Revista de Educación. (2017). Ministerio de educación: 180 años de historia, 180 años de servicio. http://www.revistad eeducacion.cl/ministerio-de-educacion-180-anos-de-historia-180-anos-de-servicio/

Uribe, M., Vanni, X., Pinares, C. \& Rozas, J. (2015). Marco para la Buena Dirección y el Liderazgo Escolar (Vol. 3). República de Chile: Mideduc. https://liderazgoescolar.mineduc.cl/wp-content/uploads/sites/55/2016/04/M BDLE_2015.pdf

\section{INFORMACIÓN ADICIONAL}

Cómo citar: Yeomans-Cabrera, M. M. (2022). Evolution of Educational Administration in Chile and Professionalizing School Administration in 2020. Revista Educación, 46(1). Recuperado de http:// doi.org/10.15517/revedu.v46i1.44499 